\title{
Mack Ott
}

Mack Ott is a senior economist at the Federal Reserve Bank of St. Louis. Erik A. Hess provided research assistance.

\section{Is America Being Sold Out?}

$\mathbf{T}$ balance was in surplus was in 1981. During the seven years $1982-88$, U.S. deficits averaged over $\$ 100$ billion. Capital inflows from foreign investors have reduced the U.S. foreign investment position steadily from a net U.S. claim of $\$ 141.1$ billion at the end of 1981 to net foreign claims on the United States of $\$ 368.2$ billion at the end of 1987.

Much of the commentary on this reversal has presumed the loss of U.S. economic sovereignty, declining opportunities for American labor, and a reduction in the U.S. standard of living. In rebutting these concerns, analysts have generally concentrated on selected aspects of the phenomenon. For example, recent articles have focused on the relative pace of foreign direct investment, in particular, Japanese direct investment, while others have singled out the benefits of capital inflows for both American investors and labor $^{1}$

This article takes a broader perspective to review the full range of concerns about foreign investment, both from a logical and an empirical vantage. The public concerns about the flow of foreign investment and its anxiety about the implications of the U.S. net international debtor status are each addressed. We begin with an overview of recent public opinion polls about foreign investment in the United States, and then consider the data on foreign investment. The potential for a foreign takeover of the U.S. economy and the pattern of foreign investment in the United States relative to U.S. investment abroad are examined.

\section{POWEGN TNVESTMENT WN TME

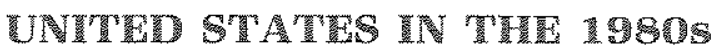

In assessing the implications of foreign investment in the United States during the 1980s, it is useful to examine three dimensions of the foreign capital inflows. First is the perception of foreign investment as reported by the media and recorded in public opinion polls. Since perceptions are often as important as facts, it is appropriate to begin with them. If there were no perceived threat, it is unlikely that any policy actions would be considered; certainly, the threat of foreign ownership of U.S. assets would not be an issue in the public forum. Second is the pattern of foreign investment. The concern seems to be chiefly that foreigners will obtain control of certain U.S. industries vital to
1Anderson (1988) focuses on direct investment misperceptions, Little (1988) discusses the relatively small magnitude of both direct and portolio investment, Makin (1988b) discusses the Japanese investment patterns in the United States, Rosengreen (1988) discusses direct investment by foreigners and compared with U.S foreign direct investment and Weidenbaum (1988) argues that capital inflows are beneficial. Francis (1988) recounts an interview with Mitton Friedman in which he argues that the U.S. foreign asset position is understated to the extent that he doubts the U.S. is a net debtor. Ulan and Dewald (1989) estimate adjustments to obtain a corrected U.S. net international investment balance. From a different vaniage, Hweko and Chediek (1988) describe the runous consequences following Argentine dictator Juan Peron's drive for "economic independence" through import substitution and restrictions on foreign investment. 
national security, industries traditionally dominated by U.S. firms, or high-technology industries. Third is the reported magnitude of foreign investment. If the magnitude of such investment is negligible, there cannot be much threat to U.S. overall interests. If the magnitude is substantial, the inflow of foreign capital must be evaluated on its merits.

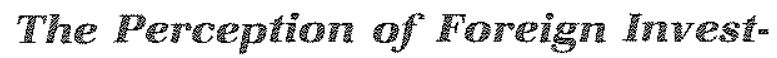 mentin the Unilued States}

Opinion polls unambiguously reveal that the American public is concerned about increased foreign ownership of U.S. firms and real estate. ${ }^{2}$ A poll by the Roper Organization in March 1988 found that 84 percent of the respondents thought that foreign companies buying more companies and real estate in America is not "a good idea for the U.S." In the same poll, by a 49 percent to 45 percent plurality, respondents disapproved of new jobs for Americans in foreign-owned plants, and at least 72 percent thought that foreign companies' investments should be restricted. ${ }^{3}$ In May 1988, a CBS News/NewYork Times survey found that 51 percent of a national sample agreed that the "increase in foreign investment poses a threat to American economic independence." ${ }^{\prime 4}$ Similar findings were reported by other polling firms. ${ }^{5}$

Moreover, the uneasiness is not limited to Americans outside of the opinion-making elite Last year, Sen. James Exon of Nebraska supported legislation "to give the Pentagon the right to veto" foreign takeovers of defense contractors; this provision was ultimately incorporated in the 1988 trade act. The political attractiveness of the issue is very strong:

Actions from Japanese land purchases in Hawaii to a British corporate takeover attempt in pitsburgh fuel grass-roots worries. "The farther away you get from Washington,' the greater the reaction 'that America

${ }^{2}$ For a comprehensive accounting of this view, see Tolchin and Jolchin (1988). Other briefer accounts, supporting in varying degrees the Tolchins' concerns, are in Baer (1988). Burgess (1989), Fieman (1988), Jenkins (1988), Norton (1988), O'Reilly (1988), Skrzycki (1988), and "MF. Greenspan on the Gas Tax" (1988). Even those who make their skepticism obvious-such as Friedman (1988), Kinsley (1988), Makin (1988a,b), "Buying into a Good Thing" (1988)--imply that the notion has received such frequent airing as to become conventional wisdom.

3Baer (1988), p.24.

4"Opinion Roundup" (1988).

shamilton, Frederick \& Schneiders reponted that " 78 percent of Americans favor laws limiting foreign investment in should belong to Americans,' says one antitakeover group official. ${ }^{6}$

The political furor and public uneasiness continue in early 1989. A controversial bill calling for greater disclosure by foreign investors was scheduled for a quick vote in the House of Representatives but was withdrawn by the Speaker of the House after an "explosion of protest in the Bush administration." In a survey for the Washington Post-ABC News Poll in mid. February 1989, "Forty-five percent said Japanese citizens should not be allowed to buy property in the United States, and eight of 10 said there should be a limit on how many U.S. companies the Japanese should be allowed to buy."8

\section{The Pattern of Foreign Investment in the United States in the $1980 \mathrm{~s}$}

There has been pronounced opposition to direct investment in the United States by foreigners, especially the Japanese. Direct investment is defined as a 10 percent or greater ownership share in a firm. Foreign direct investment in American firms has been the focus of the greatest unease. Such investment can take place either through stock purchases or the creation of new enterprises in the United States by foreigners, with or without U.S. part. ners. The seriousness of this concern is exemplified by excerpts from an editorial by Malcolm Forbes:

\section{BEFORE JAPAN BUYS TOO MUCH OF THE}

\section{U.S. $A$.}

We must instantly legislate a presidentially appointed Board of Knowledgeables whose approval would be required before any foreign purchase of any significance would be allowed of any consequential U.S. company-regardless of size.... It's one thing for the Japanese and Germans and others to buy U.S. government bonds to finance our huge trade imbalances with them. But it's a

real estate and business" [Jenkins, p. 45) and Smick Medley \& Associates found that "nearly 80 percent of Americans outside of the opinion-making elite would like to limit foreign buying, and 40 percent want to halt it altogether. 'Joe America is nervous and suspicious,' says the firm's president, David Smick. 'He is worried about losing control over his destiny." [Fierman, p.54]

5Jarosiovsky (1988).

7 Bimbaum (1989).

sMorin (1989). 
Figure 1

\section{U.S. vs. Foreign Direct Investment}

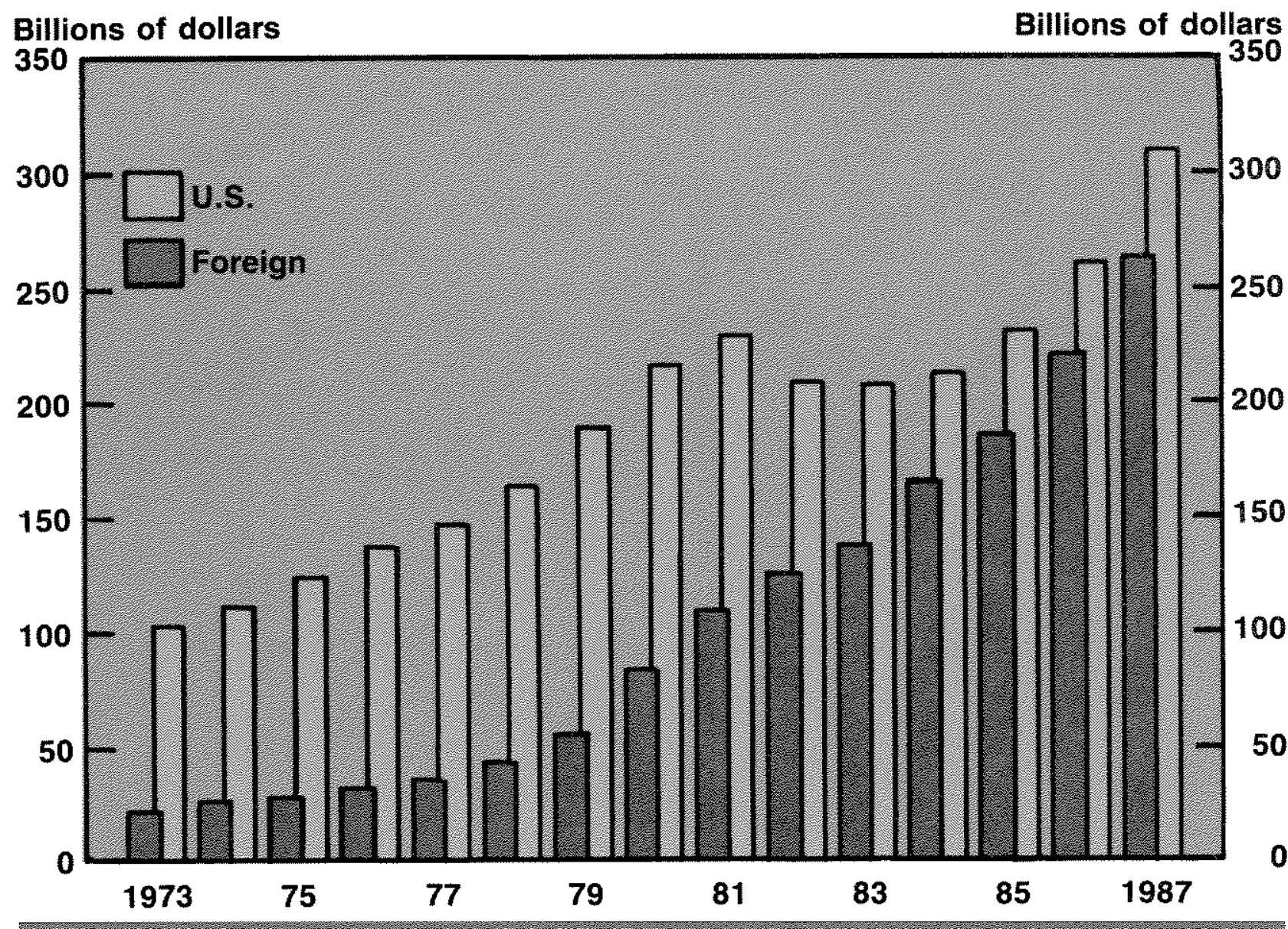

whole and totally impermissible other thing for them to use their vast billions of dollars to buy great chunks of America's big businesses, or take over the high-tech, medical or other strategic, vital U.S. concerns. ${ }^{9}$

Figure 1 shows that since the advent of floating exchange rates in the early $1970 \mathrm{~s}$, foreign direct investment in the United States has grown faster than U.S. direct investment abroad-an annual growth rate of 18.7 percent vs. 7.6 percent. Consequently, the relative size of foreign direct investment has risen-from about 22 percent of U.S. foreign direct invest- ment in 1975 to about 85 percent in 1987 . Of the $\$ 41.5$ billion of direct U.S. investment by foreigners in 1987 , nearly half, $\$ 19.1$ billion, was in U.S. manufacturing.

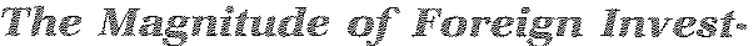 ment in the United States in the 198he}

Table 1 shows the estimated composition of foreign investment in the United States and of U.S. investment abroad at the end of 1975 and 1980-87. ${ }^{10}$ These data reveal that, since 1975 ,

using an accounting price of $\$ 42.22$ per troy ounce. If its value were computed using a value closer to its market value in the 1980 s, say $\$ 400$ per ounce, the entry in table 1 for U.S. official gold would be about $\$ 100$ billion rather than $\$ 11$ billion. 


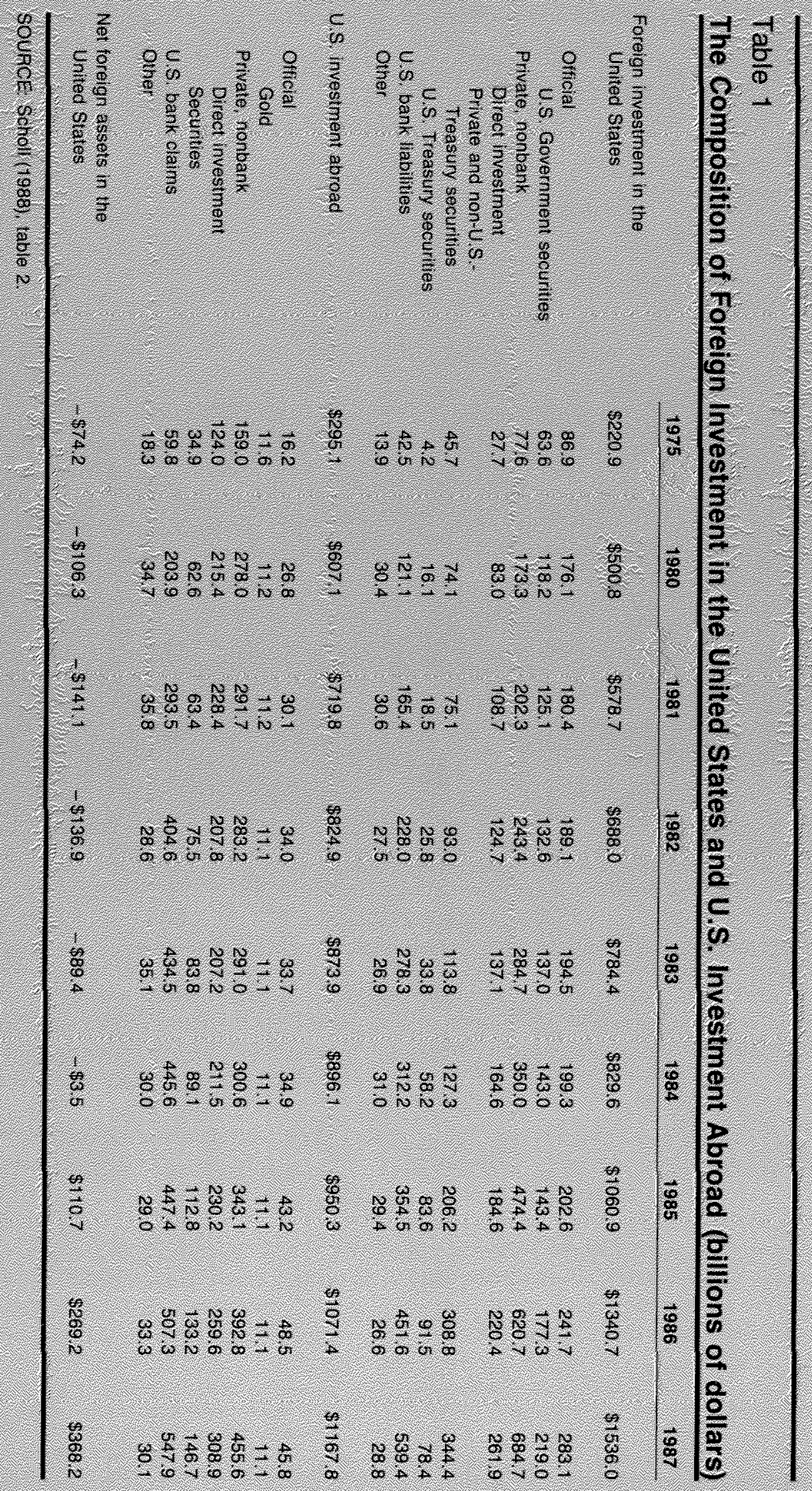


foreign assets in the United States have increased much faster than U.S, assets abroad. This pattern of faster foreign asset growth is even more pronounced if the comparison is made from 1981, the last year of an American trade surplus, to 1987. From a net claim on foreigners of $\$ 141.1$ billion, the United States has become the world's largest debtor, with estimated net liabilities to foreigners of $\$ 368.2$ billion. During this interval, foreign assets increased by 165 percent compared with 62 percent for U.S. assets abroad.

The disparity in accumulation is even greater for assets held by private investors, that is, total foreign investment less U.S. securities held by foreign governments and central banks. Over the seven years 1981-87, private foreign investment in the United States more than tripled, from $\$ 398$ billion to $\$ 1253$ billion. The bulk of these capital inflows have gone into foreign holdings of U.S. securities- corporate stocks and bonds and government notes and bonds-m and liabilities of U.S. banks-deposits by foreigners. Together, these two asset categories account for about three-fourths of the increase in private foreign investment in the United States, $\$ 643$ billion of the $\$ 855$ billion total.

The size of the foreign claims raises another issue, the cost of servicing the net foreign indebtedness. Peter Drucker (1988) has called this "the looming transfer crisis":

. . ours is the only major industrial country that has a significant foreign indebtedness, not only governmental but private as well, and that therefore has a significant foreign exchange requirement. By 1991 we will need close to $\$ 1$ billion to cover our foreign exchange remittances, about $\$ 500$ million for the federal debt. . . And there is no way to earn that in our foreign transactions. No way. Even if we balance our trade, we won't have that much surplus.

Starkly put, Drucker believes that the accumulation of U.S. assets by foreigners will force the United States to repudiate its debts, either directly, indirectly by inflation or by reducing the nominal value of the dollar: "As long as we can knock down the dollar without domestic inflation, I think that is the best thing to hope for." Such a policy would be injurious not only

11 "Political leaders should remember that foreign investors are very anxious to invest in the United States, and that they invest primarily for markes share and profits, and everything else is secondary." [Toichin and Tolchin (1988), to foreign investors but to U.S. interests as well. To see why, consider why foreigners invest in the United States and how U.S. labor and in. vestors each benefit from such investment.

\section{MUY DO FOREIGNRRS TNVEST IN TME UNTWED STATES:}

There are three reasons for foreign investment in the United States or for U.S. investment abroad: greater profit, lower risk and the trade deficit. The first, greater profit, is the fundamental reason, as it is for any other investment choice. The investor chooses one asset over another because it has a higher risk-adjusted rate of return. Both critics of foreign investment such as the Tolchins (1988) and defender's of unimpeded capital flows such as Makin (1988a,b) and Poole (1988) are agreed: Foreign investment is motivated primarily by profit. ${ }^{11}$ Speaking of the capital flows from Japan and Europe to the United States, Poole observes that:

Two rate of return conditions are relevant. First, Japanese saving invested in the United States is in the interest of the U.S. if the rate of return we pay to the Japanese is less than the return we earn on the invested capital, and there is no evidence that this condition is not met. Second, Japanese investment in the United States is in the interest of Japan if the rate of return Japan receives in the United States is greater than the rate of return available in Japan. Given the declines in Japan's growth fate and investment share, and evidence that the rate of return in the Japanese equity and fixed income markets is extremely low, it is highly likely that both of these rate-of-retum conditions were met from 1981 to 1985, and perhaps later. For Europe, it seems clear that the declining investment share is a supply-side problem; incentives to produce are too low because of high marginal tax rates and labor market rigidities. Europe also provides substantial subsidies to weak and inefficient enterprises. U.S. policies have, if anything, raised European growth in the $1980 \mathrm{~s}$ by providing a large market for European exports. Thus, the two nate-of-return conditions discussed for Japan also apply to Europe. ${ }^{12}$

One important implication of Poole's discussion is that Drucker's concern about being able to finance the U.S. foreign obligations becomes moot. p.271] See also Poole (1988), p.44.

12Poole (1988), pp.45-6. 
The second motivation for foreign investment is to reduce the risks of weath loss due to unforeseen exchange rate changes. ${ }^{13}$ This proposition is simply an extension of the risk reduction principle of portfolio diversification to international alternatives. Portfolio diversificationspreading wealth across several assets rather than a single security-reduces losses due to unforeseen events.

Similarly, exchange rate risk can be hedged by holding several assets denominated in different currencies rather than all in a single cur. rency. The investor's wealth is insured against rising or falling by the full amount of any unforeseen exchange rate change. A corollary of this is that multinational firms can reduce the unforeseen variability of their production costs and market sales by producing and selling in several countries rather than in a single one.

The third reason for foreign investment is that it accompanies trade deficits. Foreign investment induced by higher yields or portfolio diversification occurs whether or not international trade is in balance; however, trade deficits imply that net foreign investment must occur in the amount by which trade is in deficit. ${ }^{14}$ Yet it would be incorrect to infer from this accounting identity that trade deficits cause foreign capital inflows. In other words, foreign investment is not undertaken simply to finance the trade deficit; indeed, it may well be that the capital inflows cause trade deficits:

The international accounts too, are more likely be driven from the capital side than the merchandise side. In this era of instant capital transactions, a year's worth of world trade amounts to only a week's worth of capital flows. The U.S. trade deficit arose when U.S. banks stopped exporting capital to developing nations, and when, because of the Reagan tax cuts, the U.S. economy was the only growth opportunity in the world. These developments resulted in a tremendous net capital inflow; the deficit in merchandise trade was necessary to balance the equation..$^{25}$

Thus, capital flows appear to be generated by investors' self-interested profit-seeking. There is broad agreement that, whatever other effects international capital flows may have on domestic economies, foreign investment makes investors and sellers of assets wealthier than they would be if their investment and sales were restricted to domestic assets and buyers. Nonetheless, this leaves open the issue of how labor is affected by international capital flows.

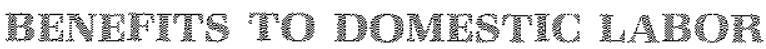 OR WOPMEN WNVESTMENT}

Labor and the owners of capital share the value added in production created by transforming raw materials into output. Capital is just a generic term for the tools, buildings, land, patents, copyrights, trademarks and goodwill that labor uses to convert one set of goodsraw materials-into another-finished output. The value of each factor of production in a market economy is its opportunity cost, that is, what the raw materials, labor or capital could produce in their most profitable alternative application.

In most cases, labor and capital are complementary, so that an increase in the quantity of one raises the productivity, hence, the value

\footnotetext{
$\$ 3$ Anticipated changes in exchange rates are reflected in the differences between the rates of return on assets in ditferent currencies. For example, if it is widely anticipated that the Brijish pound sterling will decline by 5 percent in exchange value vs. the dollar in the coming year, then the interest rate on British securities will be 5 percen higher than the interest rate on U.S. securities of similar risk. Fhis relation between interest and exchange rates is known as interest rate parity; for a discussion, see Koedijk and Ott (1987), pp. 5-7.

14 Actually, the recorded capital inflows-the capital acoount balance-have been persistently smaller than the broadest measure of the trade deficits-the current account balance-throughout the 1980 s. This error-me statistical discrepancy - has averaged over $\$ 20$ billon annually, which is between one-seventh and one-fifth of the current account deficit. For a review of the relation between the international trade and capital accounts and the statistical discrepancy, see Ott (1988), pp 3-13.
}

15Bartley (1988). See also Tatom (1987, 1989). Poole (1988), p. 42 , points out that "the issue of causation is complex and should be discussed with care." Heller (1989), p. 2, notes that foreigners are financing attractive investments for which U.S. total saving is insufficient:

...the [domestic government] deficit is stifl substantial in relatior to domestic savings and uses up funds that are needed for private sector investment. Thus tar the US economy has enjoyed the con. fidence of foreign investors, preventing serious 'crowding out' of the private sector in financial markets.

Wayne Angell, Heller's colleague on the Board of Governors of the Federal Reserve System, also has observed that the capital inflows are beneficial:

"I'm not irrifated or upset about capital inflows into the United States. Capital inflows do tend to increase our productivity." "Capital Inflows Cailed Helpful" (1988) 
of the services, of the other. For example, providing an auto mechanic or a carpenter with more tools increases the amount or quality of work they can accomplish; this increase in productivity leads to a rise in their wages, or, at the same wages, to an increase in the number of them employed.

Consequently, to the extent that foreign investment is an increment of capital that would otherwise not be available for labor to use, the foreign capital must unambiguously be beneficial to labor. ${ }^{16}$ Equally true, the availability of foreign capital lowers the cost of capital to owners; this makes additions to plant and equipment cheaper, makes possible some investment projects that otherwise would not occur and raises the value of firms. ${ }^{17}$ Thus, even if the foreign capital does not directly affect the ownership of the firm, it benefits labor and asset owners by lowering interest rates, the cost of capital.

This discussion can be summarized in five postulates about the expected gains and losses from the addition of foreign capital:

(i) Labor gains as the incremental capital raises the productivity of labor, increasing the amount of labor that can be employed or the wages of those who are employed;

(ii) Owners of firms-the shareholdersbenefit by the lower interest rates implied by higher asset prices;

(iii) Consumers gain as a result of the lower prices of goods implied by the increased labor productivity;

(iv) The profitability of financial intermediaries may decline since the value of their services in bringing borrowers and lenders together is inversely related to the supply of capital. Moreover, the entry of foreign financial intermediaries makes the industry more competitive, which also tends to reduce the rate return;

(v) Savers may lose interest income as a result of lowered interest rates due to the greater capital availability. This loss is offset, to some extent, as they receive capital gains on their existing fixed-rate portfolio holdings for the same reason as in (ii).

Since foreign investment raises the amount of capital available, labor productivity rises as does the absolute income of labor. Labor is better off with more capital than with less, and the nationality of the investor is a matter of indifference to labor. ${ }^{18}$

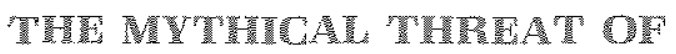

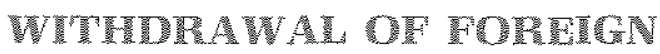 CAPITA}

In early 1989, the U.S. economy continues its longest peacetime expansion on record, so the dangers of foreign investment are posed as the potential calamity of an abrupt foreign withdrawal. This scenario was described by a
${ }^{16}$ Recent media discussions of worker views on foreign ownership of their firms have reveated a general absence of hostility by workers and their unions, emphasizing instead the benefits of the employment made possible by the capital inflow. Holusha (1989) quotes two automobile workers at the Nummi joint veniure of Toyota and General Motors as follows:

"I can't honestly say I like it better [than wher it was a G.M. plant]. but l'm working and that's better."

and

"We got a second chance fiere, and we are trying to take advantage of it. Many people don't get a second chance."

The Tolchins'(1988) single ou Volkswagen of America as being "a notable exception to the antimunion flavor of many foreign owned companies." (p. 178$)$ ronically, the other foreign automakers castigated by the Tolchins continue operations and employment of labor in the United States, while Volkswagen ceased U.S. production in 1988.

17 The elimination of restrictions on foreign owhership can raise the wealth of comestic asset owners, as recently illustrated in a policy change by Nestle, a Swiss corporation; see Dulforce (1988a). In late November 1988, Nestle announced that, henceforth, it would sell registered shares to any buyer, whether or not that buyer was a Swiss resident. As a result of the eradication of the distinction between its two types of common stock, registered (formerly restricted to residents) and bearer (available to nonresidents), common shares of both types now sell for about the same price. Before the change, bearer shares had sold for about twice the price of registered shares. See Financial Times Market Staff (1988). Removing the restriction on foreign buyers' ability to buy the resident shares realized a 40 percent wealth gain for Swiss resident shareholders. Nestle reportediy makes up about 11 percent of the capitalized value of the Swiss stock market shares, and its decision may influence other Swiss corporations' equity policies. This change opens up the possibility of foreign ownership of Swiss corporations; ap parently, Swiss Nestle stockholders are willing to bear this cost. The Governor of the Swiss National Bank also has argued that the market for financial assets in Switzerland must not discriminate on the nationality of the buyer if the country is to remain an impottant center for capital transactions; see Dullforce (1988c). Similar arguments are offered in a discussion of the European Commumity's eradication of capital restrictions by Greenhouse (1988).

18In the 1988 Presidential campaign, the Democratic candidate, Michael Dukakis, told a group of workers at a St. Louis automotive parts plant, "Maybe the Republican ticket wants our children to work for foreign owners... but that's not the kind of a future Lloyd Bentsen and I and Dick Gephardt and you want for America." The workers addressed by the candidate thad been employed by an Italian corporation for 11 years. 'Dukakis-Bentsen: Gephardt ${ }^{+5}(1988)$. 


\section{Figure 2 \\ U.S. Dollar Exchange Rates vs. Japan, U.K. and West Germany}

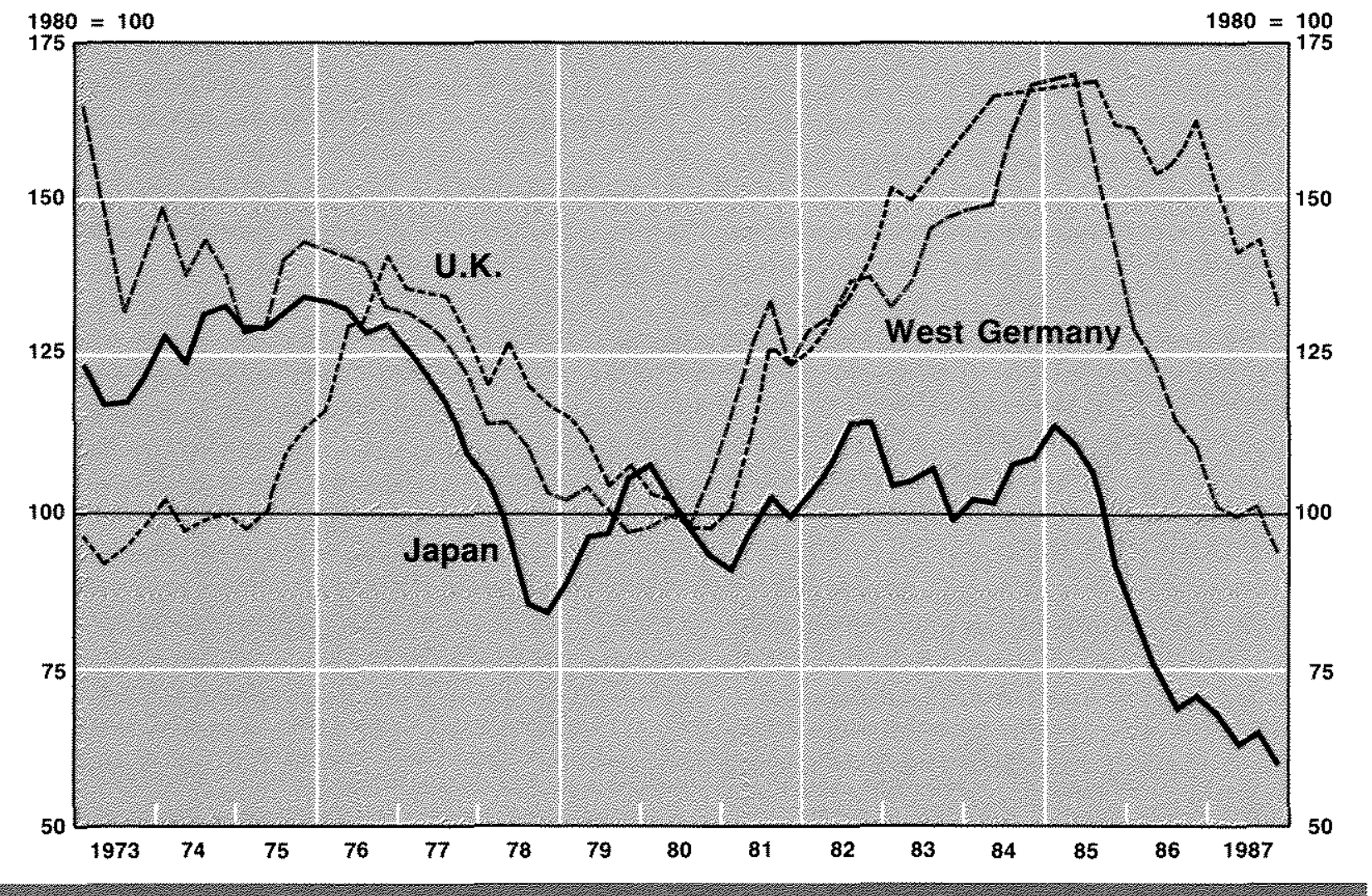

prominent New York investment banker as follows:

The dollar will eventually fall, he notes, and when it does and interest rates decline in a period of recession, foreign investors would withdraw their portfolio investments, triggering a banking crisis. These foreign investors then could use their inflated portfolios to make direct investments of American industry at "bargain basement prices. ... We will have financed our deficit by putting up permanent assets."

This scenario entails the confluence of four events: a decline in the dollar's exchange value; a cyclical decline in U.S. interest rates; a withdrawal and subsequent re-entry of foreign investment; and a banking crisis induced by the foreign withdrawal. Thus, to evaluate the dangers posed by foreign ownership of U.S. assets, one must investigate not just the likelihood of each of these events but their joint likelihood, including whether they are mutually consistent.

\section{Mecinge of}

From its peak in February 1985, the exchange value of the dollar averaged against the principal industrial currencies has fallen more than 40 percent. $^{20}$ As shown in figure 2 , it has fallen by about one-third against the pound, by almost one-half vs. the yen and by over twofifths in terms of the Deutsche mark. Yet, there has been no sign of a widespread flight from
${ }^{19}$ Attributed to Felix Rohatyn, p.28, in Tolchin and Tolchin (1988); this scenario is repeated nearly verbatim on pp. $197-98$ and again on p. 201. See also Baer (1988), Fier man (1988), Jenkins (1988), Makin (1988a,b) and Norton (1988).
20The trade-weighted exchange rate of the dollar against the other Group of Ten countries plus Switzerland hit a peak of $158.43(1973=100.00)$ in February 1985 ; if was below 90.0 in late 1987 and has a value of 91.88 in January 1989 , a 42 percent decline from its early 1985 peak. 
dollar assets. Even the record stock-market crash of October 1987, when the dollar's exchange value was at its nadir, did not suffice to trigger a massive withdrawal of foreign capital. ${ }^{2 x}$

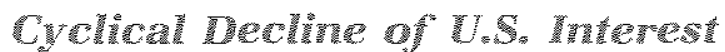

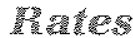

Generally, differences in interest rates in one currency vs, another are just sufficient to offset the anticipated depreciation of the higherinterest currency vs, the lower-interest currency as reflected in their forward exchange rate. ${ }^{22}$ While interest rates do decline in recessions, the benefit to an investor from selling U.S. assets and shifting to another currency at such times is limited by the likely state of other economies. The world's major economies are so economically integrated that periods of recession in the U.S. economy are generally also periods of recession in the other economies in which attractive substitute investments would be available. Consequently, to the extent that both interest rates and asset prices were to fall in the U.S. economy, the same pattern is likely to have occurred in the rest of the industrial economies as well, so a shift from U.S. to foreign assets would accrue no profit. If other economies' asset prices and interest rates had not fallen with those in the United States, then the depreciation of the dollar's exchange rate would obviate the benefit of such a withdrawal.

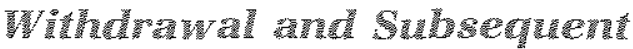

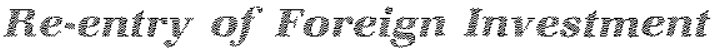

Investors withdrawing their funds from U.S. assets must do it in two steps-first selling the asset and then using the cash (dollar) proceeds to buy another asset, either another U.S. asset or a foreign currency. An investor selling an asset from a portfolio is, by that action, buying something else-a stock, a bond, a piece of real estate, a quantity of money denominated in some currency. ${ }^{23}$ When the dollar proceeds are exchanged for foreign currency, some other investors will acquire the original asset and the U.S. dollars. In the spirit of the scenario, if only domestic U.S. investors are buying the U.S. assets from the prior foreign owners, both a U.S. capital outflow and a sharply declining dollar exchange rate will occur. The capital outflow can only occur if the United States has a trade surplus. ${ }^{24}$ In reality, massive withdrawals of foreign capital cannot occur in the short run. Prices and exchange rates adjust first; international payments flows adjust with a sub. stantial lag. Nonetheless, if this unlikely abrupt swing from trade deficit to surplus were to occur because of the foreigners' panic sales, the assets would end up in U.S. investors' hands at considerably lower prices. If foreigners repur. chased them shortly thereafter, the result would be increased prices and an appreciation of the exchange value of the dollar with the resulting profit aceruing to domestic owners.
21 in part, this is simply an illustration of the interconnectedress of the world's economies. All major stock market around the globe crashed together:

Al major world markets decined substantialy in that month IOctober 1987], which is issell ar exceptonal fact that conirasts with the usual modest correlations of returns across countries... The United States had the fitth smallest decline, i.e., the fith best performance, in local currency units. However, because the dolkar declined against most currencies, the U.S. pertormance restated in a common currency was only 11 th out of $23 . . .1$ Aln attempt was made to ascertain how much of October's crash could be ascribed to the normal response of each country's stock market to a worldwide marketmovement. A world market index was constructed and found to be statisticaly related to monthly returns in every country during the period from the beginning of 1981 up unti the month before the crash. The magnitude of market response differs matertaly across countries. The response coefficient, or "beta" was by far the most stat'stically significant explanatory variable in the October crash. It swamped the infuences of the institutional market characteristics. Foll (1989), pp.65-6

22This relation between interest rate differences and anticipated exchange rate changes (primarily due to inflation rate differences) is called covered interest parity (ClP). The evidence supporting the absence of profitable speculative opportuntites due to ClP is overwhelming. While there is also evidence of risk premia in interest differentials, such evidence also suggests that these premia are a return for the cost of risk-bearing, noi a pure profit, See Koedijk and Ott (1987).

\footnotetext{
23The scenario at this point makes a distinction between toreign investors' portfolio and direct investment: "...withdraw their portfolo investments...then could use their inflated portfolios to make direct investments at bargain basement prices..." This presumes a distinction between bond and stock prices which is inconsistent. According to the scenario, the dollar and all other U.S. asset prices fall, so it would be irrelevant where foreign investors ${ }^{2}$ portfolios were inithally invested. Moreover, since direct investment is simply a 10 percent or greater holding in a corporation, the distinction between "portfolio" and "direct investment" holdings of common shares is one of degree, not of kind.

${ }^{24}$ lt is unlikely, but conceivable that a swap of U.S. assets for foreign assets could take piace without any impact on the balance of payments; however, this would require that the assets exchange in exactly balanced total values, the value of U.S. assets sold equaling the value of foreign assets sold. In contrast, the scenario being reviewed postulates a declining dolar, suggesting that the U.S. assets are no longer as desirable as they were at their prior prices. Consequently, with falling U.S. assel prices and foreigners engaging in net sales, a capital ouffiow is implied. This can only occur if the trade balance is registering a surplus.
} 


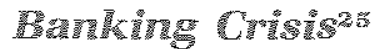

Here the scenario presumes that foreigners, having sold their portfolios, then convert their dollar deposits to nondollar currencies. To do so, they must buy these currencies from others who, in turn, end up holding dollar deposits. This would put downward pressure on the dollar's exchange rate and would be associated with a capital outflow from the United States. Such substantial withdrawals-even if replaced dollar for dollar in aggregate-would increase the uncertainty entailed in asset-liability management decisions at individual depository institutions.

In particular, this uncertainty would complicate the matching of the duration of assets and deposit liabilities. The likely response of depository institutions to these portfolio shifts would be an increase in their demand for reserves, reflected in a rise of the federal funds rate. Yet, the stress of an abrupt rise in deposit turnover-whether or not it is associated with a net outflow of funds from depository institutions-does not necessarily imply a banking crisis. Such an implication would require that the Federal Reserve take no action to accommodate an abrupt shift in the public's portfolio preferences. The Fed can and has accommodated such increases in the public's demand for liquidity and the rise in depository institutions' demand for reserves. ${ }^{26}$

\section{Orerview of the Foreigz

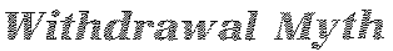

In summary, the scenario is extremely unlike ly to occur. It is internally inconsistent and depends on inept U.S. monetary policy actions and irrational investment behavior by both domestic and foreign investor. Since interest rates are linked through integrated international capital markets, the presumed low U.S. interest rates and a depreciating dollar are inconsistent. Investors, U.S. resident and foreign, are unlikely to believe that the U.S. monetary authorities would be passive in the event of a U.S. banking crisis. They could profit by buying U.S. assets at prices temporarily depressed by any general foreign withdrawal and subsequently selling them back to other chagrined but wiser foreign investors. In short, rational expectations and the profit motive induce competitive behavior which nullifies the threat of widespread foreign capital withdrawal, the same profit motive that induced the foreign investment in the first place. ${ }^{27}$

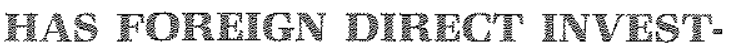

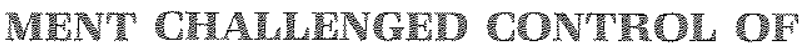 DOMESTIC U.S. TNDUSTRIES?}

\section{Misperceptions about the distribution of} foreign ownership pervade discussions about foreign investment in the United States. First, as can be seen in table 1, most foreign investment is concentrated in portfolio and bank deposits. In 1987, foreigners held only about 17 percent of their U.S. assets in direct investment; if official assets are excluded, the share of direct investment rises to about 21 percent. In contrast, U.S. direct investment abroad is about 26 percent of the total or 27 percent of private investment. As the table shows, U.S. direct investment abroad exceeds foreign direct investment in the United States. Moreover, the excess of U.S. direct investment widened in 1987 to $\$ 47$ billion from $\$ 39.2$ billion at the end of 1986 .

The acceleration of U.S. foreign direct investment beginning with 1985 is obvious in figure 1. U.S. foreign direct investment fell from 1981 to 1982 and was stagnant until 1985; during this

\footnotetext{
${ }^{25} \mathrm{~A}$ "banking crisis" can be defined as a widespread loss of confidence in the solvency of depository institutions resulting in runs on banks or abrupt rises in interest rates to deter withdrawals. From the public's point of view, such shifts in portfolio preferences away from deposits can be characterized as an increase in liquidity preference. Such a crisis could very well be precipitated by sharp declines in stock and bond prices if deposit holders feared that banks' direct losses on portfolio investments or indirect losses through loans secured by securities endangered their deposits.

${ }^{26}$ For example, by a combination of increased open market purchases of U.S. securities and the indication of greater accommodation through the discount window, the Fed obvated a potential liquidity crisis in the U.S. financial system following the October 1987 stock market crash.
}
${ }^{27}$ Another interpretation of this scenario is that it is simple lobbying for restrictions on foreign buyers and foreign in- termediaries. The scenario is intended to engender doubt about the benefits of unhindered foreign capital inflows. The policy implication contingent on finding the scenario credible would be to restrict U.S. investment by foreigners and foreign investment intermediaries. These restrictions would lower the supply of capital and raise interest rates and other costs of financing domestic investment and cor- porate resiructuring. As a result, the services of domestic financtal intermediaries would rise in value. In short, the argument is of a piece with all regulatory arguments for restrictions on entry or output-that the increased safety, purity or quality of the licensed practitioners justifies the reduced supply and higher cost. See Stigler (1971).


period, foreign direct investment in the United States accelerated. Since 1985, however, U.S. investment abroad has outpaced foreign direct investment in the United States. While there is a lively debate about why this resurgence of U.S. direct investment has occurred, most analysts argue that it reflects the tax reforms of 1986:

Nonresidential [U.S.] fixed investment rose substantially in 1983484 , but reached a peak in 1985 and then fell somewhat. The tax reform discussion, which began in earnest with the Treasury I tax proposal in November 1984, killed the investment boom. Further evidence for this view is that U.S. direct investment abroad rose substantially at the same time. ${ }^{28}$

The second misperception about foreign direct investment in the United States is the apparent belief that the Japanese are the principal foreign direct investors. ${ }^{29}$ This notion is incorrect. As figure $3 a$ indicates, Japanese direct investment in the United States ranks a distant third behind that of the British and the Dutch. In fact, the European Community holds about three-fifths of the foreign direct investment in the United States- $\$ 157.7$ billion of the $\$ 261.9$ billion in 1987-nearly five times the Japanese stake. Of the total investment, direct, portfolio and bank deposits, Burgess (1988) notes that "at the end of 1987, Europeans had holdings of $\$ 785$ billion, compared to Japan's $\$ 194$ billion ...[of] assets of all kinds-wholly owned companies, stocks, bonds, bank deposits, real estate."

The third misperception is that foreign direct investment is concentrated in the manufacturing sector. As shown in figure $3 a$ and $3 b$, the share of U.S. direct investment by foreigners in manufacturing is just over one-third, 35 percent, slightly less than the 41 percent share of U.S. direct investment abroad in manufacturing. In terms of country shares, the Japanese have less than one-sixth of their U.S. direct investment in manufacturing. The top four areas of direct investment show substantial similarity. In descending order, manufacturing, trade, petroleum and finance are the largest foretgn direct investment areas in the United States, while manufacturing, petroleum, finance and wholesale are the largest U.S. direct investment areas abroad.

Considered at the level of individual firms, the Japanese record is even less obtrusive. Rosengren (1988) reports that Japan's acquisition of 94 U.S. companies during 1978-87 ranked fifth compared with the 640 taken over by the British, 435 by the Canadians, 150 by the Germans and 113 by the French. Considering the year 1987, the Japanese tied for fifth place with the Germans at 15 acquisitions, well behind the pace of the British (78), the Canadians (28), the French (19), and the Australians (17). Rosengren argues that these company purchases tend to be reciprocal in two respects. First, the U.S. list of companies purchased has nearly the same country rank order as the foreign purchases in the United States, and the particular industries also were similar for the U.S. and foreign direct. Second, both U.S. and foreign firms tend to make acquisitions of firms in their own industries as a means of extending their markets.

The upshot of Rosengren's study is that foreign acquisitions of U.S. firms have exhibited much the same patterns as U.S. acquisitions of foreign firms with a twist reflecting the increasing international integration of business: "[M]any of the foreign acquisitions are partnerships between foreign investors and U.S. banks and investment companies." ${ }^{30}$

\section{IS THETE ANY CREDIBLE DANGER FPOM FONUIGN CAPITAL:}

Any credible threat from foreign investment must ultimately depend on the share of foreign

\footnotetext{
2apoole (1988), p. 46. See aiso Tatom (1987, 1989).

29For example, see O'Reilly (1988). This view also is implicit in the excerpt of the editorial by Malcolm Forbes (1988) on pages 48-49. Its inaccuracy is addressed in Makin (1988b) and Rosengren (1988).

3eposengren (1988), p. 50, illustrates this with a clear example of the financial integration of takeovers:
} pany. Depending on how the deal is structured, those who pro-
vide the tinancing may have a stobstartial stake in the outcome
of the acquisition. For example, wher Beazer, a British compary
announced its $\$ 1.85$ bition hostile bid for Koppers, much of the
financing was provided by a U.S. company, Shearson/American
Express. Shearson/Arrerican Express not ony provided $\$ 500$
milion in debt financing, it also agreed to purchase 46 percent of
equity.

Classifying ars acquistion as "foreign' can be misleading since the bulk of the purchase may be financed by a comestic com. 
Figure 3a

\section{Distribution of Foreign Direct Investment in the United States, (\$261.9 Billion), 1987}

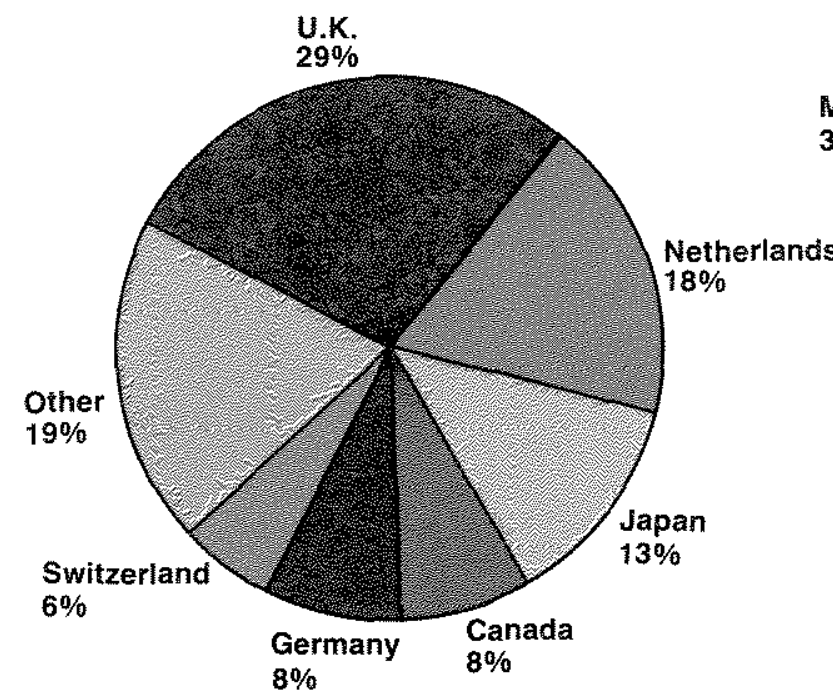

by Country

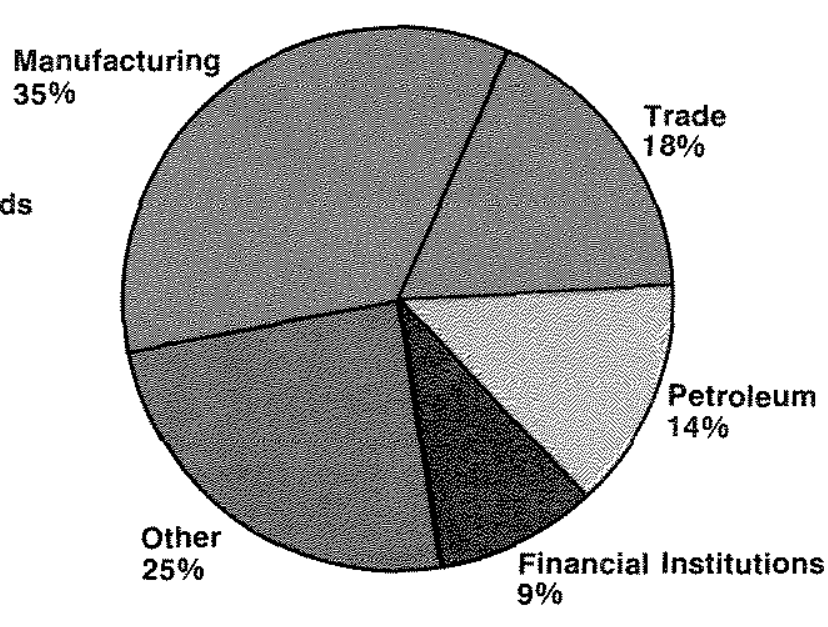

by Industry

Figure $3 b$

Distribution of U.S. Direct Investment Abroad, (\$308.8 Billion), 1987

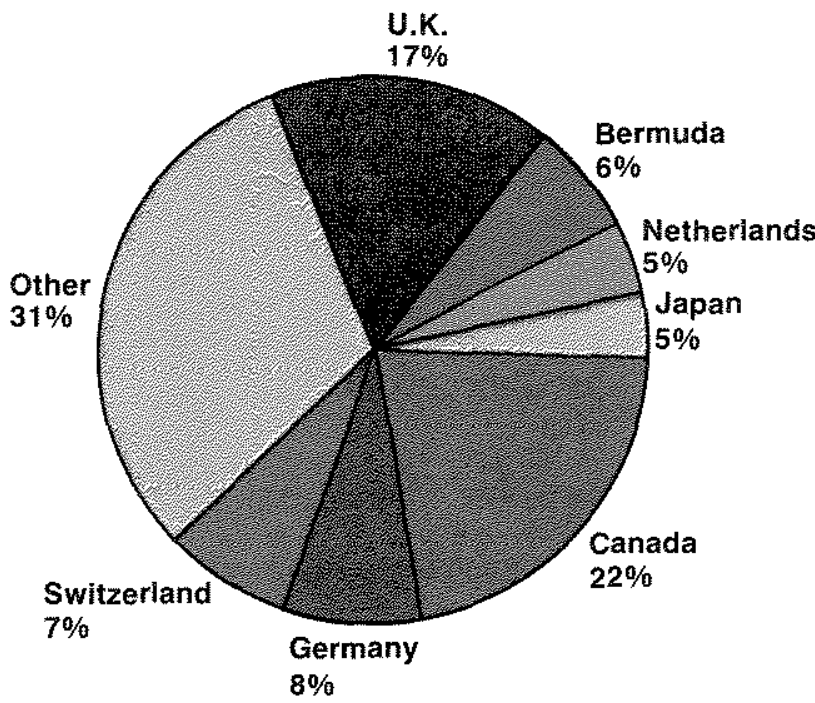

by Country

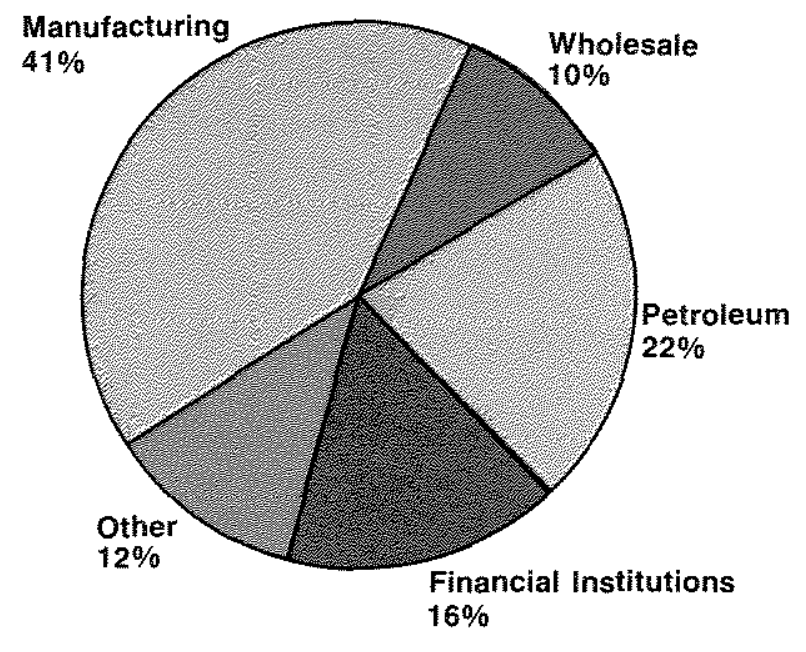

by Industry 


\section{Figure 4 \\ U.S. Net Reproducible Fixed Capital Stock at Market Prices}

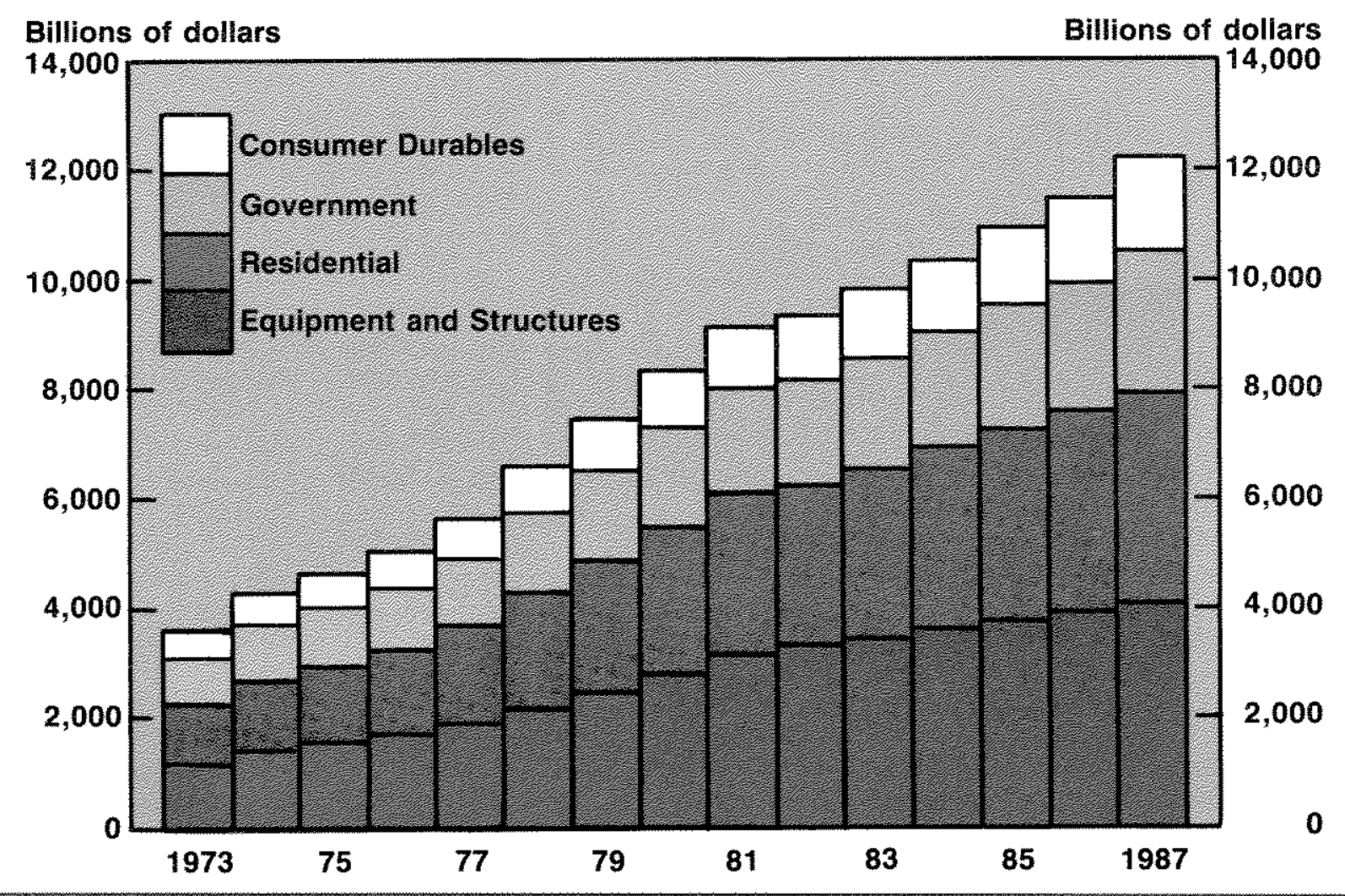

ownership of the stock of U.S. assets. That is, a small proportional share of U.S. capital held by foreigners is sufficient to preclude the possibility that foreign investment in the United States is deleterious. In this section, we show that the foreign share of U.S. capital, current and prospective, is too small to support the critics' concern.

\section{The Miniscule Shave of Foreign Ownership of U.S. Capital}

The market value and the composition of the U.S. reproducible fixed net capital stock from 1973 to 1987 is shown in figure 4 . From 1973 , when its market value was $\$ 3.6$ trillion, it has grown to $\$ 12.2$ trillion at the end of 1987 . During the period of large U.S. current account deficits beginning in 1982, its annual increase has averaged more than $\$ 0.5$ trillion-that is, more than five times the average capital inflow-an annual growth rate of about 5.5 percent. Its composition in 1987 was $\$ 4.1$ trillion of producers' plant and equipment, $\$ 2.4$ trillion of government capital, $\$ 4.0$ trillion of residential capital and $\$ 1.7$ trillion of consumer durable goods such as automobiles, household fur* nishings and equipment. ${ }^{31}$ For purposes of this analysis, we will consider the share of the net U.S. reproducible tangible capital stock (less consumer durables) that the net foreign investment could command as collateral.

The composition of U.S. assets held abroad and foreign assets held in the United States are shown in table 1. Considered as a potential
31Government capital, valued at its current estimated replacement cost, consists of government buildings, plant and equipment used in government production and roads, bridges, waterway improvements, etc. State and locat governments hold about two-thirds of the public capital stock and the federal government one third. 
Figure 5
Ratio of Net Foreign Assets to Net Reproducible
Capital Stock Excluding Consumer Durables

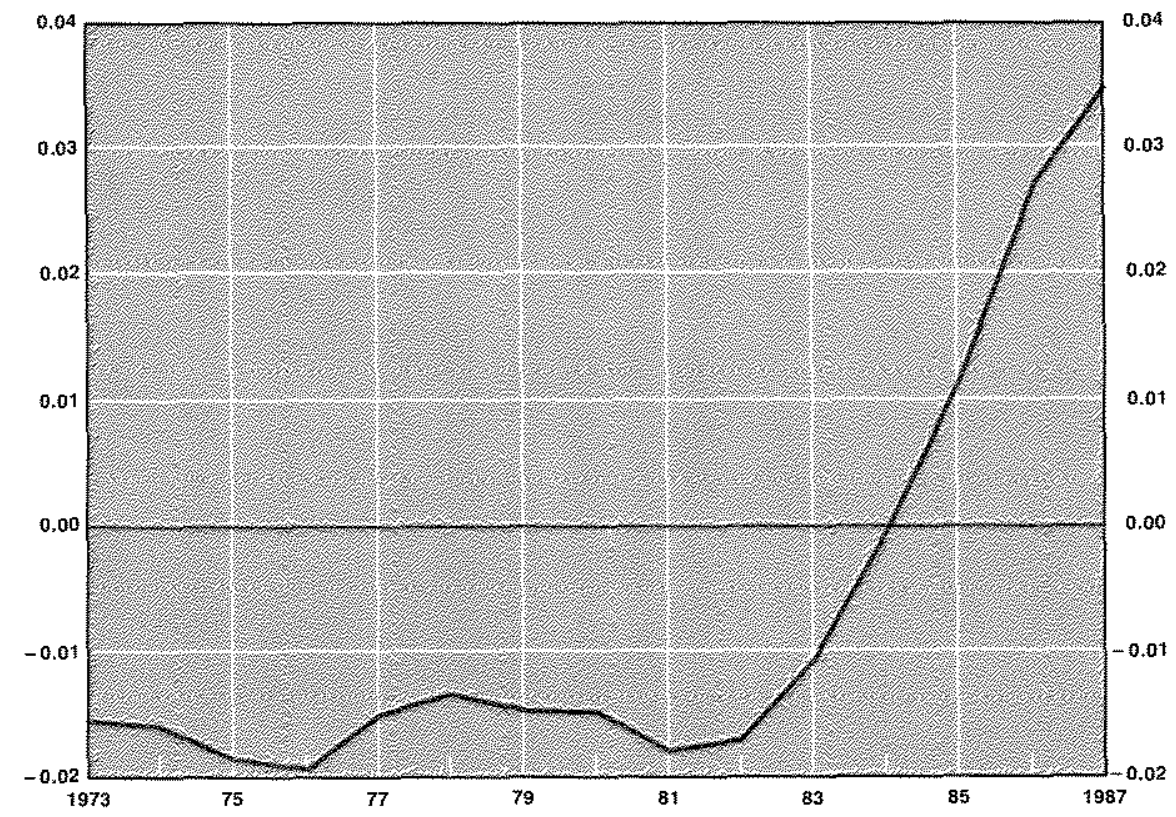

claim collateralized by the U.S. capital stock, the estimated foreign holding of U.S. claims at year. end $1987, \$ 1.54$ trillion, was about 12.5 percent of the U.S. reproducible capital stock and 14.6 percent of the nonconsumer capital stock. Considered as a claim on the producer capital stock, $\$ 4.1$ trillion, it amounted to a 37.4 percent claim. Subtracting estimated U.S. assets abroad at year-end $1987, \$ 1.17$ trillion, from the foreign claims yields net foreign assets in the United States, \$0.37 trillion, so that the percentage foreign claim on the net U.S. reproducible nonconsumer capital stock at the end of 1987 was 3.5 percent.

In summary, the net curfent share of U.S. assets owned by foreigners is implausibly low to substantiate any potential cornering of U.S. asset markets. Even so, this leaves open the question of whether the trend of increasing foreign ownership poses any such likelihood.

\section{Sustained Capital In lows fre sufficient 10 Threater U.S. Economic Sovereigm}

The U.S. Commerce Department estimates that the U.S. international investment position became a net foreign claim in 1985 for the first time since 1914, $\$ 110.7$ billion (see table 1). Figure 5 shows this net foreign investment claim as a share of the net U.S reproducible nonconsumer capital stock. Reflecting the U,S. trade deficts during the 1980s, the foreign claim has grown at an avenage of over $\$ 80$ billion per year since 1981. Since becoming a net claim, the foreign percentage claim has fisen to 3.5 percent of this U.S. wealth measure.

Even if the capital inflows persisted indefinitely at their 1988 level of about $\$ 120$ billion, this need not result in an eventual foreign control of the U.S. economy in the sense of majority foreign ownership of U.S. nonconsumer assets. This is because the U.S. capital stock also is growing. If either the inflation of replacement prices of physical capital or real capital accumulation is fast enough, the share of foreign capital could rise for a period of years and then decline. The maximum the foreign share would attain and the time at which it would top out vary with the assumed rates of capital stock growth and the rate of capital price appreciation. 


\section{Figure 6 \\ Foreign Share of Net U.S. Reproducible Capital \\ Stock Excluding Consumer Durables Collaterized by Net Foreign Investment with Constant Capital Inflows and Declining Capital Inflows}

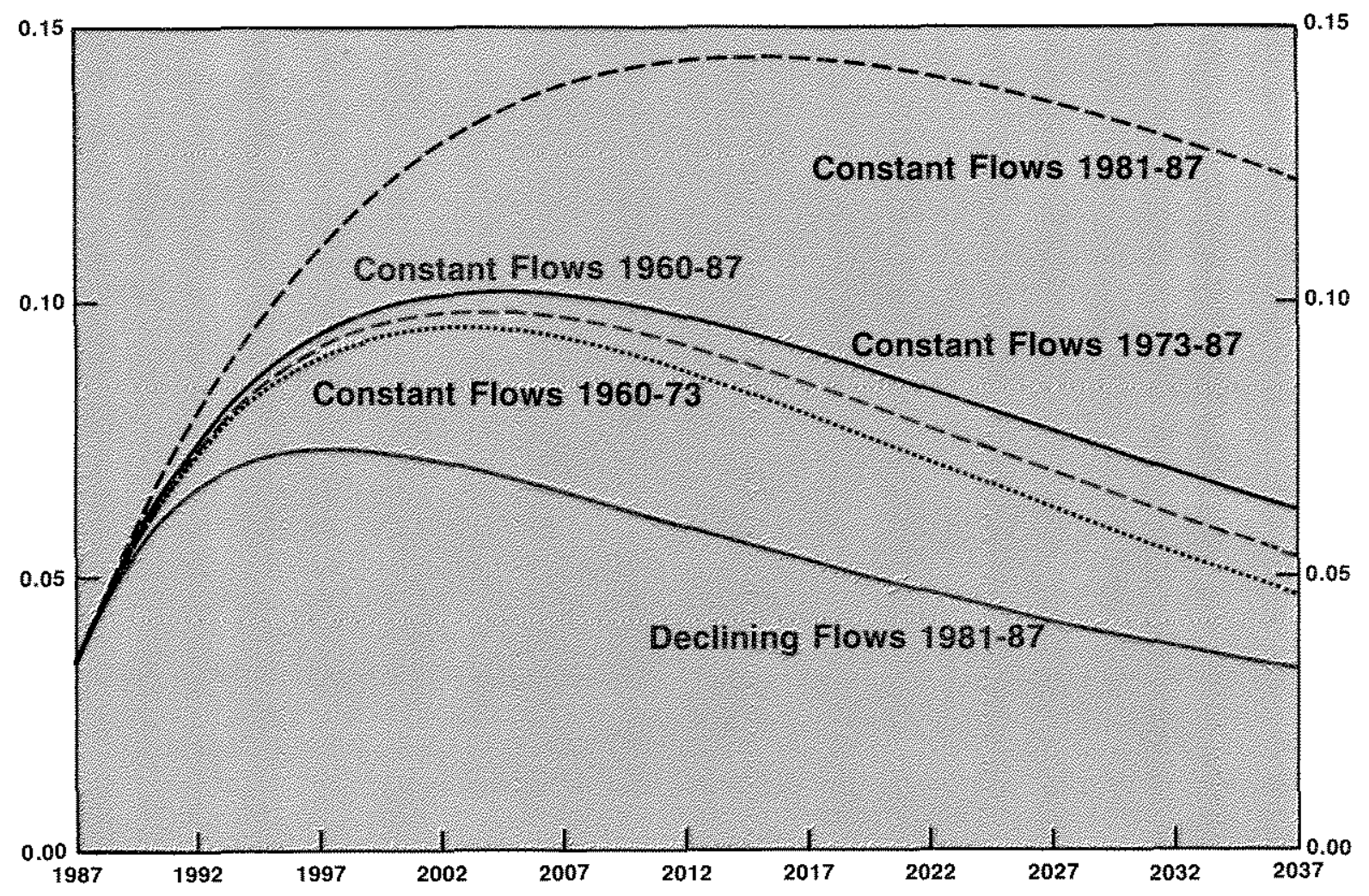

The U.S. capital stock grows each year by the amount by which gross investment in new buildings, roads, housing and industrial plant and equipment exceeds the scrappage and depreciation of the existing stock. The market value of this stock also rises with inflation. As was shown in chart 4 , the estimated market value of the U.S. nonconsumer capital stock grew from $\$ 7.9$ trillion at the end of 1981 to $\$ 10.5$ trillion at the end of 1987 . Over this period, the implicit annual rate of inflation of capital stock replacement cost has averaged about 2.3 percent, and the annual growth of the real net stock (at 1982 prices) has averaged about 2.2 percent. The sum of these two effects in the 1980 s has implied a nominal capital stock growth rate of 4.5 percent. Combining these recent trends, we can determine the long-term consequences of a continued capital inflow. ${ }^{32}$

As shown in figure 6 , under these assumptions, which are most favorable to the threat scenario, the foreign share actually would rise to a maximum of 14.4 percent in the year 2015
32The period 1981-87 and the constant $\$ 120$ billion inflow are used in this discussion as they maximize the growth of and the peak share attained by foreign capital. More plausible rates are considered below. Nonetheless, the fact that even indefinitely susfained capital inflows of over $\$ 100$ billion would be insufficient to support any traumatic restructuring of the U.S. economy is consistent with Mussa's conjecture about surprisingly large equilibrium
U.S. current account deficits: As a result of the higher growth rate of the U.S. population, its relatively younger age distribution, the size of the U.S. economy and its attractive investment opportunities, ". ... we should have an equilibrium current account deficit of roughly one percent of our GNP." See Mussa (1985, p.146). In terms of the 1988 level of GNP of $\$ 5$ trillion, this would imply an equilibrium capital inflow of $\$ 50$ billion. 
and then decline ${ }^{33}$ Since the assumed sustained capital inflow is probably larger than most analysts would assume, this is a worst-case scenario. For example, under growth and inflation rates averaged over the the full floating-Fate era, 1973-87, the constant $\$ 120$ billion capital inflow would generate a peak share of 10.2 percent in 2004. Finally, if the capital inflow declines over the near future as it has since 1987 , then the foreign share would peak in 1997 at about 7.3 percent.

Consequently, the growth of the foreign share of U.S. capital, while large by 20 th century experience, does not approach the share necessary to corner the market. Even when expressed as a claim on a subset of U.S. weath-excluding consumer durable goods, land, and human capitaland presuming an investment pattern which foreign investment has not exhibited, the share of foreign investment does not present a credible takeover threat to the American economy.

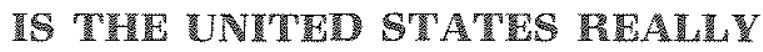 A NET DEDTOP?}

Much of the concern about the economic security of the United States was triggered by the Department of Commerce estimate that the U.S. net international investment position became negative in 1985 (see table 1). The proximate cause of the declining U.S. net investment position is the U.S. current account deficits since 1981. "There is no question that the U.S. international investment balance has declined as a result of the relatively faster foreign investment in the United States than U.S. investment abroad. In other words, there is no question that the net capital flows have been into the
United States. Conversely, there is a very real question whether the U.S. position has yet become negative. The primary basis for this skepticism is that direct investment is recorded at its historic cost, which understates the cur. rent market value by amounts that grow over the years.

Recently, Ulan and Dewald (1989) have estimated the net U.S. investment position [NIIP] adjusting for the understatement of U.S. direct foreign investment:

When direct investment is revalued to market, we estimate that the U.S. NIIP as about $\$ 400$ to $\$ 600$ billion more than the official NIIP indicates through the end of 1987 , though, by all but the earnings measure, the NIIP is below its peak values of 1980 or $19811^{34}$

In terms of the official Commerce Department data reported in table 1 , this would imply that the U.S. position at the end of 1987 was a net U.S. clam on foreigners of between $\$ 31$ and $\$ 231$ billion. If the midpoint of this range is used as the appropriate point estimate, then given the estimated $\$ 120$ billion capital inflow in 1988 , the United States still held a net claim on foreigners as of the end of 1988 .

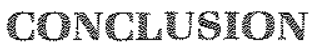

The joint implication from analysis of the three aspects of foreign investment in the United States - the effects on labor and investors, the threat of withdrawal, and the relative size of the foreign claim-is that the capaital inflows are beneficient. The capital inflows benefit labor and management, entrepreneurs and investors alike. Workers benefit from the greater abundance of tools; the increased capital raises labor's produc-

\footnotetext{
33The year $t$ foreign share, $s\left(t^{*}\right)$, of the U.S. nominal nonconsumer capital stock is the ratio of the sum of the initial foreign net holding, $\$ 368.2$ billion, of the nominal capital stock plus the integral of the annual capital inflow, $\$ 120$ billion, reduced by the rate of inflation of capital stock replacement cost, to the growing real capital stock whose 1987 value is $\$ 10,514.3$ bilion:

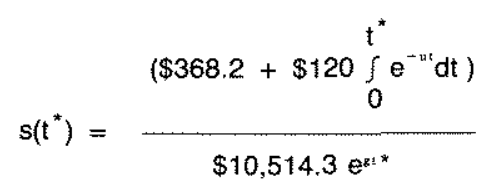

where $s\left(t^{*}\right)=$ share of net U.S. nonconsumer capital collateralized against net foreign investment at end of year $t^{*}$;

$u=$ implicit rate of inflation of net capital stock's replacement cost;
}

$g \equiv$ growth rate of real net capital stock due to in vestment, foreign and domestic.

34ulan and Dewald use three different methods to estimate the capital gains in the U.S. foreign direct investment and the foreign direct investment in the United States: stock price indexes, corporate earnings, investment goods price deflators. Their estirnates based on the capitalization provide the largest estimate of the U.S. undervaluation and provide the clearest rebuttal of the transfer problem outlined by Drucker (1988). Their adjustments omil the U.S. gold stock, which would add about $\$ 90$ billion to the U.S. position as reported by the Commerce Department (see note 3 above); however, they also do not allow for a potential write-down of U.S.bank holdings of LDC debt which they report would reduce the U.S. investment position by about $\$ 50$ billion. 
tivity and increases its employment or wages. Management benefits from the greater capital availability and lower interest rates; the capital inflows facilitate long-range planning, and the rise in labor productivity enhances management productivity as well. Entrepreneurs benefit from the lower interest rates due to a greater abun. dance of capital; this increases the range of profitable projects and new firm startups. And investors benefit since a more capital-abundant economy is a richer economy, regardless of who owns the capital.

The United States has imported capital throughout the 1980s, but far from signaling an economy in decline, such investment by foreigners is a measure of the economy's vigor. William Baumol aptly sums up this positive aspect of foreign capital inflows: "...relatively declining nations send their funds abroad because their decline makes it profitable to invest elsewhere." ${ }^{\prime 3}$ Clearly, foreign investment in the United States does not signify the selling out of America.

\section{REFERENCES}

Anderson, Gerald H. "Three Common Misperceptions about Foreign Direct investment," Economic Commentary, Gleveland Federal Reserve Bank, July 15, 1988.

Baer, Donald. "Anxiety in America's Heartland," U.S. News and World Report (April 25, 1988), p 24.

Bartley, Robert L. "Whither Voodoo Economics?" Wall Street Journal, August $18,1988$.

Bimbaum, Jeffrey $\mathrm{H}$. 'Wright Angers Some With Call for Vote On More Disclosure by Foreign Investors," Wall Street Journal, February 17, 1989.

Burgess, John. "British fnvestments in the U.S. Out-pace Japan's, Study Finds," Washington Post, Janwary 27, 1989.

"Buying into a Good Thing." National Review (October 14 , 1988), p.17.

"Capital Inflow Called Helpful." New York Times, May 25, 1988.

Drucker, Peter. "The Looming Transfer Crisis," Instjtutional Investor, June 6, 1988, p. 29.

"Dukakis-Bensten-Gephardt," Wall Street Joumal, October $11,1988$.

Dullforce, William. "Swiss Life Wins Battle for LaSuisse", Financial Times, August 8, 1988a.

"Nestle to End Foreign Shares Discrimination;" Financial Times, November 18, 1988b.

"Nestle Breaks Market Mold," Financial Times, November 22, $1988 \mathrm{c}$

Fierman, Jaclyn. "The Selling of America (Cont'd)," Fortune (May 23, 1988), pp. 54-64.

${ }_{35}$ "Buying into a Good Thing." (1988). Another economist, Jurg Niehans, expresses the idea in the context of net investment this way: "Countries are debtors if their invest-
Financial Times Market Staff. "Nestle Bearers Plummet after Hours on Shock News," Financial Times, November 18, 1988.

Forbes, Malcolm S. "Before Japan Buys Too Much of the USA," Forbes (January 25, 1989), p. 17.

Francis, David R. "US Not a Debtor Nation, But the Idea Doesn't Worry Economist," Christian Science Monitor, July 2, 1988.

Friedman, Milton. "Why the Twin Deficits Are a Blessing," Wall Street Joumal, December 14, 1988.

Greenhouse, Steven. "Europeans Adopt Plan to End Curbs on Capital FLows," New York Times, June 17, 1988.

Helfer, H. Robert. "Mr. Heller Examines the US Economy and Monetary Policy," Speech at the University of St. Gallen, February 2, 1989, BIS Review, no. 35 1989, pp.1-7

Hewko, John, and Jorge Chediek. "The Economic and Political Awakening of Argentina's Peronists:" Wall Street Journal, March 11, 1988.

Holusha, John. "No Utopia, but to Workers It's a Job," New York Times, January 29, 1989.

Jarosiovosky, Rich. "Foreign Takeovers Emerge as an Increasingly Hof Political Issue," Wall Street Joumal, Aptil 1, 1988.

Jenkins, Holman, Jr. "Anxiety Fises as Foreigners Buy American," Insight (March 28, 1988), pp. 44-45.

Kinsley, Michael. "Deficits : Lunchtime is Over"; Time (October 3, 1988), pp 27-28.

Koedijk, Kees, and Mack Otl. "Risk Aversion, Efficient Markets and the Forward Exchange Rate," this Revjew (December 1987), pp. 5-13.

Little, Jane Sneddon. "Foreign Investment in the United States: A Cause for Concern?" New England Economic Review (July/August 1988), pp 5t-58.

Makin, John $\mathrm{H}$. "Is Foreign Investment Taking Over America?" Washington Post, February 28, 1988a.

"Japan's Investment in America: Is It a Threat?" Challenge (November/December 1988b), pp. 8-16.

"Mr.Greenspan on the Gas Tax." Washington Post, March 7, 1988.

Morin, Richard. "Americans Rate Japan No. 1 Economic Power," Washington Post, February 21, 1989.

Mussa, Michael. "Commentary on "Is the Strong Dollar Sustainable?' " in The U.S. Dollar - Recent developments, Outlook, and Policy Options (Federal Reserve Bank of Kansas City, October 1985).

Niehans, Jurg. International Monetary Economics, (John Hopkins University Press, 1984).

Norton, Robert E. "Fleeing from the Almighty Dollar," U.S. News and World Report (June 13, 1988), pp 47-48.

"Opinion Roundup." Public Opinion. (November/ December 1988), p.29

O'Reilly, Brian. "Will Japan Gain Too Much Power?" Fortune (September 12, 1988), pp. 150-153.

Ott,Mack. "Have U.S. Exports Been Larger than Reported," this Review (September/October 1988), pp. 3-23.

ment opportunities are greater than their wealth and are creditors if their wealth exceeds their investment opportunities." Niehans (1984), p. 107 
Poole, William. "U.S. International Capital Flows in the 1980s.' "in Shadow Open Market Committee, March 1988, pp. 42.47 .

Roll, Richard W. "The International Crash of 1987;" in Robert Kamphuis, Roger Kormendi and JW. Henty Watson, eds., Black Monday and the Future of Financial Markets (Mid America Institute, October 1988), pp. 37-70.

Rosengren, Eric S. "Is the United States for Sale? Foreign Acquisitions of U.S. Companies," New England Economic Review (November/December 1988), pp. 47-56.

Scholl, Russell B. "The International Investment Position of the United States in 1987," Survey of Current Business (June 1988), pp. 76-84.

Skrzycki, Cindy. "America on the Auction Block." US. News and World Report (Match 30, 1987), pp. 56-58.

Stigler, George. "Theory of Regulation," Bell Journal of Economics and Management Science (Spring 1971), pp 3-21.
Tatom, John A. "Will a Weaker Dollar Mean a Stronger Economy?" Joumal of international Money and Finance, 1987, pp 433-47.

"U.S. Investment in the 1980s: the Real Story", this Review, (March/April 1989), pp. 3-15.

Tolchin, Martin, and Susan Tolchin. Buying into AmericaHow Foreign Money Is Changing the Face of Our Nation, (Times Books, 1988).

Ulan, Michael, and William G. Dewald. "The U.S. Net inter" national Investment Position: The Numbers Are Misstated and Misunderstood"' U.S. State Department mimeo, February 199

Weidenbaum, Murray. "Foreign Investment Could Be an Asset, Not a Liability," Christian Science Monitor, August 24, 1988. 